\title{
PERCEPTIONS OF EFL LEARNERS REGARDING EFFECTIVENESS OF TWITTER IN ENGLISH LANGUAGE LEARNING PROFICIENCY AT UNIVERSITY LEVEL
}

\author{
Irfan Ullah Khan ${ }^{1 *}$, Mati Ullah' ${ }^{2}$, Khurshed Iqbal ${ }^{3}$, Mahraban Alam ${ }^{4}$, Iftikhar Ahmad ${ }^{5}$ \\ ${ }^{1 *}$ Department of Education \& Research, University of Lakki Marwat, KP, Pakistan; ${ }^{2}$ Department of Education \& \\ Research, University of Lakki Marwat, KP, Pakistan; ${ }^{3}$ Center for Management and Commerce, University of Swat KP, \\ Pakistan; ${ }^{4}$ Centre for Management and Commerce, Shangla Campus, University of Swat, KP, Pakistan; ${ }^{5}$ Riphah School \\ of Leadership (RSL) Faculty of Management Science (FMS) Malakand Campus, Riphah International University, \\ Pakistan. \\ Email: ${ }^{1 *}$ thescholaredun@gmail.ocm, ${ }^{2}$ educationistmrn@gmail.com, ${ }^{3}$ kiqbal@ uswat.edu.pk, \\ ${ }^{4}$ mehar.mann26@gmail.com, ${ }^{5}$ iftikhar.ahmad@riphah.edu.pk
}

Article History: Received on $18^{\text {th }}$ June 2021, Revised on $27^{\text {th }}$ June 2021, Published on $29^{\text {th }}$ June 2021

\section{Abstract}

Purpose of the study: Social media and online social media sources play a vital role in our daily routine life. This study's main purpose was to highlight the role of Twitter in English language learning proficiency development at the university level.

Methodology: In the study, the researcher analyzed the perception of EFL learners regarding the effectiveness of Twitter in English language learning proficiency at the university level by taking data from sampled respondents through a self-developed questionnaire on a 5-Points Likert scale. John Curry's (1984) sample size rule of thumb, convenient sampling technique, validity, and reliability of the research instrument were ensured in the study.

Main Findings: The key findings of the current study revealed that in social media, Twitter has a high positive role in promoting, polishing, and developing English Language learning by using computers, laptops, or smartphones for the teaching-learning process in this regard. The study's main findings indicated that Twitter is very helpful to facilitate teachers and learners regarding the development of the English language as a second language.

Applications of this study: The current study may be highly significant and effective for students, parents, teachers, the public, policymakers, and the government to apply it for developing language proficiency via the practical use of Twitter.

Novelty/Originality of this study: The study will be a quite novel and original way of promoting and developing language proficiency by using media resources, especially Twitter, to attain the desired objectives, i.e., developing language proficiency via Twitter.

Keywords: EFL Learners, Development, Language Proficiency, Twitter, University Level.

\section{INTRODUCTION}

Now in the present age of science and technology, every aspect of life is influenced by technology. It means that technology is used in all walks of life, and it has revolutionized the lifestyle and plays a pivotal role. Technology is available everywhere, not only in the classroom; it starts from web 1.0 and switches to 1.0 and web 2. 0. Basically, this entire web 2.0 refers to the use of the internet in all walks of life and its facilitation as well. Selwyn (2009) also highlighted the use of web 2.0 and its application worldwide and may not be neglected, but rather we may say that it is used in all walks of life and has made the lifestyle easy for the people. Here the main point is that nowadays, the quantity of users has been increased to an immense limit while using web 2.0. Srinivas (2010) also highlighted the importance of online social networking sights that facilitate learners to learn the English language not only inside the classroom but out of the classroom; also, there are numerous ways of learning for English language learners to improve their language learning proficiency. It means that these social networking sites have made the learning process easy for language learners to learn a language without any hesitation of space or distance. Aguilar (2018) described the importance of Twitter in learning and especially as an informal way of learning. Shahzad et al. (2021) stated the importance of computermediated instructions in English as second or foreign language learning. In this regard, if we see Twitter, then one may not wrong to say that Twitter is also an effective way of learning and improving English language learning proficiency development at the university level because there are numerous posts and reviews available which are quite helpful to improve EFL learners reading comprehension as well as the vocabulary of English language. Abu-Bakar et al. (2021) stated the value and importance of Web-2.0 tools among English language instructors of Higher Institutions, which plays a pivotal role in English language learning proficiency development at higher education institutions. Basically, the web 2.0 tools are helpful in higher education institutions in this regard that at this stage, the learners are mature enough to use web 2.0 tools and get benefits from them. Rough (2021) described the role of mobile learning in higher education. It is basically the new way of learning and an easy way of learning. Here also, if we see, then we may conclude that mobile learning plays a pivotal role in the teaching-learning process. While using a mobile phone, the Twitter role may also be not neglected because Twitter, Whatsapp, Facebook, and youtube are the various social media tools that can be used on 
android sets easily. Taskiran et al. (2018) highlighted learning a language through Twitter and its role in English language learning. It also indicates the use of Twitter in English language learning because it is an easy way of sharing posts and interacting with others. Here in this research study, the main point is that language is highlighted according to the language learning point of view that language learning is not only confined to the classroom and may learn language even outside the classroom while using various online social media sources.

\section{LITERATURE REVIEW}

Twitter is an important microblogging system that allows its users to send and receive short posts called tweets in which there is a maximum of 140 characters. The importance of Twitter may not be neglected, but rather it is most commonly used by the user to send posts and interact with others, and especially there are numerous reviews within a short time on that tweets. However, like other social media tools or sources, Twitter is also a social media site. Its main purpose is to allow its users to send posts and read other people's posts their views and thoughts about different which may be related to different aspects of life. Now so far as English language learning through social media sites like Twitter is concerned, we may say that English is a language and language is a skill so that that skill may improve through practice; Twitter is a social media tool or source that is most popular and commonly used. Ahmed (2015) also highlighted the importance of using Twitter for English language writing skills development.

The importance and value of Twitter may not be neglected like other social media sources like Facebook, WhatsApp, and youtube, etc. One of the most prominent features of Twitter benefits is that it is helpful for learners to get quick feedback not only from class fellows but also from concerned teachers or instructors when they are working on any type of assignment or project to be completed well in time. According to Dunlap \& Lowenthal (2009), the important aspect of Twitter is that it is helpful to facilitate peer tutoring and social interaction to solve academic issues. List \& Bryant (2009) highlighted that the significance of Twitter in English language learning might not be neglected; one may not wrong to say that social media sources like Twitter and other tools are not only helpful, but it facilitates users to take benefits from it without any hesitation of time and distance. Grosseck \& Holotescu (2008) revealed the value of Twitter in language learning and facilitation during communication. Borau et al. (2009) asserted that Twitter provides a platform for communication to motivate others and an easy and interesting way of communication that may not be neglected. Borau et al. (2009) investigated that twitter is quite helpful in English language acquisition. The main point here is that while using Twitter, the user may send a post to many Twitter users and then, in response, receive a number of feedback through which English language learning may become easy for learners to read the post and also the reviews which other users send in response of this post.

Tweeternet (2011) mentioned that Twitter is one of the most important social media sources and plays an important role in social media tools. Twitter is the social networking and microblogging service users like social media use, especially for short messages like 140 characters in length. This short messaging service is too much interested both for English language learners and teachers to continue their contacts regarding various topics and ideas to improve their writing skills and make them creative-minded. Therefore, millions of users, especially teachers, use Twitter for their learners. Tweeternet (2011) elaborated that teachers may use Twitter to ask short questions and answers, questions tags, and other everyday related questions to make them able to answer the questions easily and quickly and learn how to use Twitter for short messaging purposes.

Uses and gratification theory is an important theory of media, and in this present technological era, this theory is especially related to online social media. This theory is an audience-centered approach used for the understanding of mass communication. Uses and gratifications theory is an approach to understanding why and how people actively seek out specific media to satisfy specific needs. The uses and gratification theory of media is not only concerned about the role of media and what media do to people, but here it highlights that what active audiences do with media Lasswell (, 1948). Blumler \& Katz (1974) stated that people use various tools or sources of media to satisfy specific needs, especially Twitter, for their learning purposes. Ruggiero (2000) explained that UGT discusses how users deliberately choose media that will satisfy specific needs and allow one to enhance knowledge, relaxation, social interactions/companionship, diversion, or escape. It assumes that audience members are not passive consumers of media; rather, the audience has power over their media consumption and assumes an active role in interpreting and integrating media into their own lives. Unlike other theoretical perspectives, UGT holds that audiences are responsible for choosing media to meet their desires and needs to achieve gratification. Blumler \& Katz (1974) clarified the functions and approaches of uses and gratification theory that how media will be used for various purposes like social and psychological concerns, needs, expectations, mass media, different patterns of exposure, engagement, and gratifications. Blumler \& Katz (1974) described that using gratification theory is very important because it enables users to how and why people choose a specific media to satisfy their needs; as a result, they receive gratification as the audiences' roles are active. U \& G mentioned different categories, but namely, five well-known categories are cognitive, affective, personal integrative, socially integrative, and tension free needs. The importance of uses and gratification may not be neglected because of media application according to situations. Tweeternet (2011) found the use and gratification to be very important and the roles of audiences while using media. Griffin (2012) revealed that gratification theory is changed from traditional theories of media that referred to media influence to a greater extent, but this theory refers to users' use and its gratifications. 
Uses and Gratification Theory is an audience-centered approach and enables learners to use media for their purposes and to satisfy their needs. Raacke \& Bonds (2008) narrated the traditional sources of media like radio, newspaper, and television, and due to proficient use of the internet and too many online social networking sites, this theory has gained popularity and great significance. Therefore, the present study was designed in light of uses and gratification framework to make the university level mature learners regarding the role of social media for English language learning and to explore the effect of various social media sources' for English language learning proficiency development as perceived by learners themselves at the university level. Ahmed Al-Hunaiyyan et al. (2020) also highlighted the importance of online social media sources like Facebook for learning purposes. Similarly, Adanir and Muhametjanova (2021) also described students' acceptance of mobile learning for learning purposes. The importance of it may not be neglected but rather appreciated. Yasir (2020) also stated the importance of communication in the digital world. Putriand \& Wahjuwibowo (2020) have also described social media and communication strategies.

\section{PURPOSE OF THE STUDY}

The main purpose of this study was that to highlight the role of Twitter in English language learning. Thou we see in our daily routine life that students are using various social media sources and online channels very common because they have android sets and also have the internet facility that is why in other to make their concentration on English language learning proficiency development while using various social media sources like Twitter. Moreover, Twitter is an easy way of sharing posts and receiving responses (reviews) from other users as well.

\section{SIGNIFICANCE OF THE STUDY}

This study is significant in this regard that this study will highlight the importance of Twitter for English language learning purposes. Furthermore, this study will highlight the positive effect of Twitter on the English language learning process in light of previous researchers' points of view. In this study, especially in the review section, the views of previous researchers are highlighted regarding twitter's role in the English language acquisition process. Therefore, the present study will not only inform learners about the role of Twitter in the language learning process and English language teachers that how to utilize smartphones for the teaching of English as a second language and facilitate learners.

\section{OBJECTIVES OF THE STUDY}

To find out perceptions of university-level learners regarding twitter use in English language learning proficiency development (across gender groups).

To find out perceptions of university-level learners regarding twitter use in English language learning proficiency development (across discipline).

To make appropriate recommendations based on the findings of the study.

\section{HYPOTHESES OF THE STUDY}

$\mathbf{H O}_{1}$ : There is no significant difference between the perceptions of male and female learners regarding twitter use in English language learning proficiency development at the university level.

$\mathbf{H 0}_{2}$ : There is no significant difference between the perceptions of social sciences and pure sciences learners regarding twitter use in English language learning proficiency development at the university level.

\section{METHODOLOGY}

\section{Population}

Selection of population is very important in the research process because "A population comprises all the possible cases (persons, objects, events) that constitute a known whole. a Population is a group consisting of all people to whom the researcher wishes to apply findings". For example, if a researcher is interested in the language learning proficiency of young university-level learners in Khyber Pakhtunkhwa, then the population would be all university-level learners of Khyber Pakhtunkhwa. Therefore, the population of this present study is divided into two divisions:

Target Population

Accessible Population

Target Population

Target Population is a population on which findings of the study are generalized. This is a whole population from which an accessible population is derived to select a sample for the study. Therefore, the target population of this present study was all those students enrolled in MA, M.Sc. programs in public sector universities of Khyber Pakhtunkhwa.

Accessible Population

An accessible Population is a population from which a researcher selects a sample. It is a subset of the target population. 
Therefore, the accessible population of this present study was all the master level students enrolled in (Session 20152016) of the four public sector universities of southern districts in Khyber Pakhtunkhwa.

\section{Sample}

The sample size of this present study was eight hundred (800) students, both male and female, who were enrolled in MA, M.Sc programs of southern districts public sector universities of Khyber Pakhtunkhwa. But finally, data were obtained from only seven hundred and eighty-nine students (789). Therefore, for the determination of sample size, John Curry's (1984) formula was used.

Sample Size Rule of Thumb

$\begin{array}{ll}10-100 & 100 \% \\ 101-1000 & 10 \% \\ 1001-5000 & 5 \% \\ 5001+10000 & 3 \% \\ 10000+1 \% & \end{array}$

Table 1: Stratum Wise Proportionally Selected Sample

\begin{tabular}{lllll}
\hline Selected Sample & Population & Percentage & Selected Sample & Percentage \\
\hline Social Sciences Male & 6861 & $26.53 \%$ & 208 & $3.01 \%$ \\
\hline Social Sciences Female & 5970 & $23.08 \%$ & 182 & $3.04 \%$ \\
\hline Pure Sciences Male & 6848 & $26.48 \%$ & 209 & $3.05 \%$ \\
\hline Pure Sciences Female & 6178 & $23.89 \%$ & 190 & $3.07 \%$ \\
\hline
\end{tabular}

Source: Authors

Above table 1 shows the sample size very clearly because the researcher has selected the sample according to John Curry's (1984) formula of sample size. According to john curry formula of sample size, if the population is from five thousand and one to ten thousand (5001 to 10000), then $3 \%$ of the sample size is enough for it that is why the researcher has taken $3 \%$ of respondents from each stratum, i.e., total male students enrolled in social sciences (session 2015-16) were (6861) from which the researcher had taken only (208) respondents which are 3.01\%, total female students were (5970) from which the researcher had taken only (182) respondents who are also $3.04 \%$, total students of pure sciences were (6848) from which the researcher had taken only (209) which is also 3.05\%. Similarly, the total number of female students were (6178) from which the researcher had taken only (190) which is 3.07. Therefore, the above detail clearly showed that sample size is taken according to john curry's formula of sample size that if the population is (5001 to 10000), then $3 \%$ sample size is enough for it. The researcher also had a $3 \%$ sample size from each stratum because the in each strata population is more than five thousand and less than ten thousand, which is why the researcher had taken three percent from each stratum.

\section{Sampling Technique}

The researcher adopted the Multistage Sampling technique. Multistage sampling can be a complex form of cluster sampling because the population is divided into groups or clusters in this type of sampling. Then one or more clusters are chosen at random, and everyone within the chosen cluster is sampled. In other words, multistage sampling refers to sampling plans where the sampling is carried out in stages using smaller and smaller sampling units at each stage.

\section{Delimitations}

The present study was delimited only to students enrolled in master programs (MA, M.Sc.) level in public sector universities of southern districts in Khyber Pakhtunkhwa, Pakistan.

Research Design

The study was descriptive; that is why a quantitative research design was used here in this study.

\section{DESCRIPTIVE RESULTS}

Table 2: Gender-Based Frequencies

\begin{tabular}{llllll}
\hline \multirow{2}{*}{ Valid } & Gender & Frequency & Percent & Valid Percent & Cumulative Percent \\
\cline { 2 - 6 } & Male Students & 400 & 50.7 & 50.7 & 50.7 \\
\cline { 2 - 6 } & Female Students & 389 & 49.3 & 49.3 & 100.0 \\
\cline { 2 - 5 } & Total & 789 & 100.0 & 100.0 & \\
\hline
\end{tabular}


Source: Directorate of academics in each university

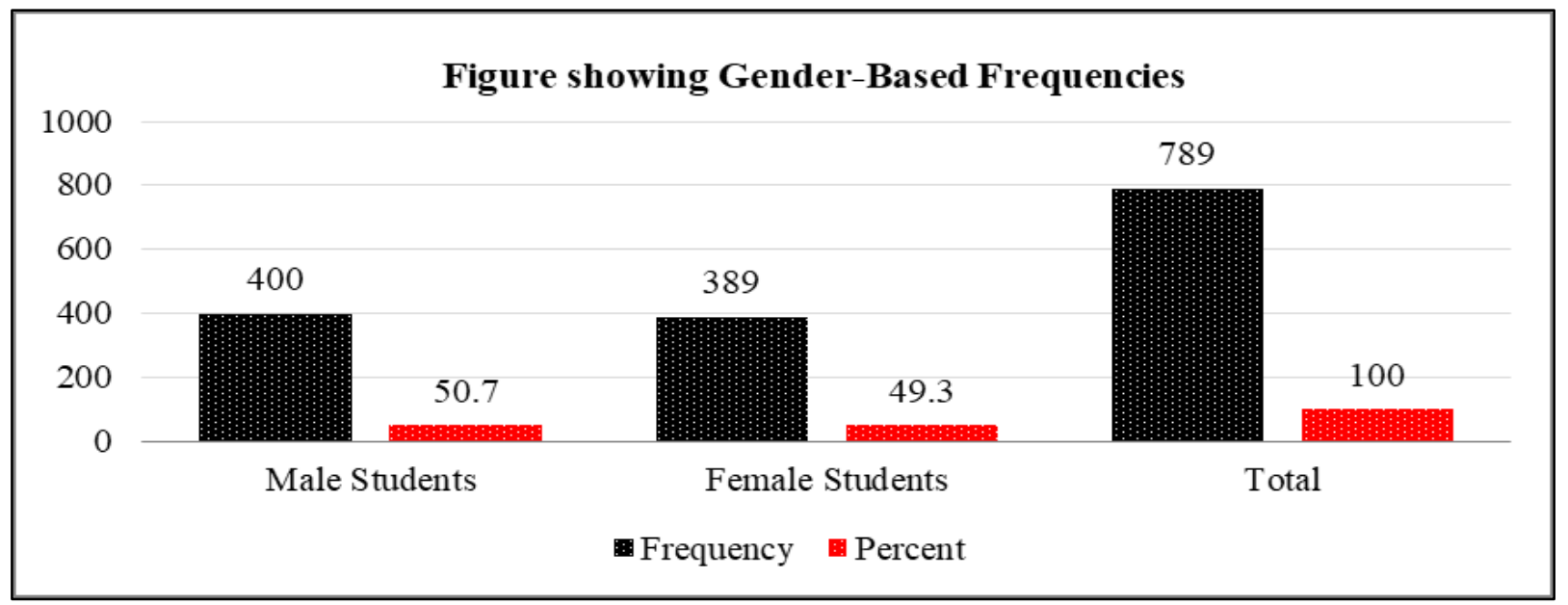

Figure 1: Showing Gender-Based Frequencies

Source: Authors

Table 2 along with the figure, revealed the frequencies and percentages regarding gender-based. The gender was attributed concerning the male and female. The respondents who participated in the present study included 400 males (50.7\%), while the female respondents were 389 (49.3\%). The analysis highlighted that the male participants were more than the female participants in the current research study. In light of the above table, the frequency of male learners is more than female respondents.

Table 3: Age-Based Frequencies

\begin{tabular}{cccccc}
\hline & Age Level & Frequency & Percent & Valid Percent & Cumulative Percent \\
\hline \multirow{3}{*}{ Valid } & 18 to 21 years & 305 & 38.7 & 38.7 & 38.7 \\
\cline { 2 - 6 } & 22 to 25 years & 303 & 38.4 & 38.4 & 77.1 \\
\cline { 2 - 6 } & 26 years and above & 181 & 22.9 & 22.9 & 100.0 \\
\cline { 2 - 6 } & Total & 789 & 100.0 & 100.0 & \\
\hline
\end{tabular}

Source: Directorate of academics in each university

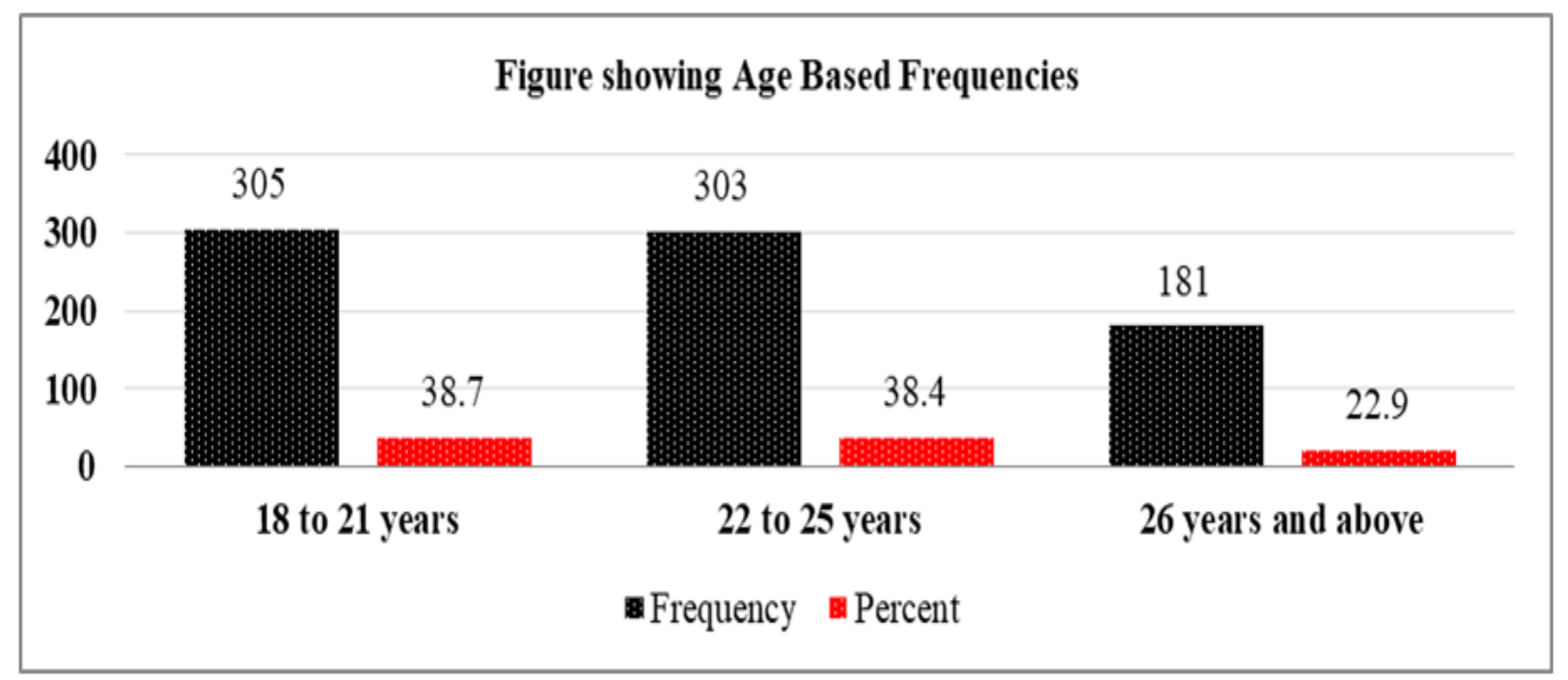

Figure 2: Showing Age-Based Frequencies

Source: Authors

Table 3 along with the figure, showed age-based frequencies and percentages. The age was attributed concerning 18 to 21 years, 22 to 25 years, and 26 years and above. In this regard, the respondents who participated in the present study, including the 305 (38.7\%), were of the age of 18 to 21 years, 303 (38.4\%) were of the age 22 to 25 years, and 181 (22.9\%) were of the age 26 years and above. Thus, the data analysis reflected that the participants were more than the age of 18 to 21 years in the current research study. 
Table 4: Discipline-Based Frequencies

\begin{tabular}{llllll}
\hline & Discipline & Frequency & Percent & Valid Percent & Cumulative Percent \\
\hline \multirow{3}{*}{ Valid } & Social Sciences & 390 & 49.4 & 49.4 & 49.4 \\
\cline { 2 - 6 } & Pure Sciences & 399 & 50.6 & 50.6 & 98.7 \\
\cline { 2 - 6 } & Total & 789 & 100.0 & 100.0 & 100.0 \\
\hline
\end{tabular}

Source: Directorate of academics in each university

Table 4 along with the figure, showing discipline-based frequencies and percentages. The discipline was attributed concerning the social sciences and pure sciences. In this regard, the respondents who participated in the present study, including 390 (49.4\%), have the discipline of social sciences, while the respondents of pure sciences included in the current study were $399(50.6 \%)$. The analysis indicated that the pure sciences participants (Students) were more than the social sciences participants in the current research study.

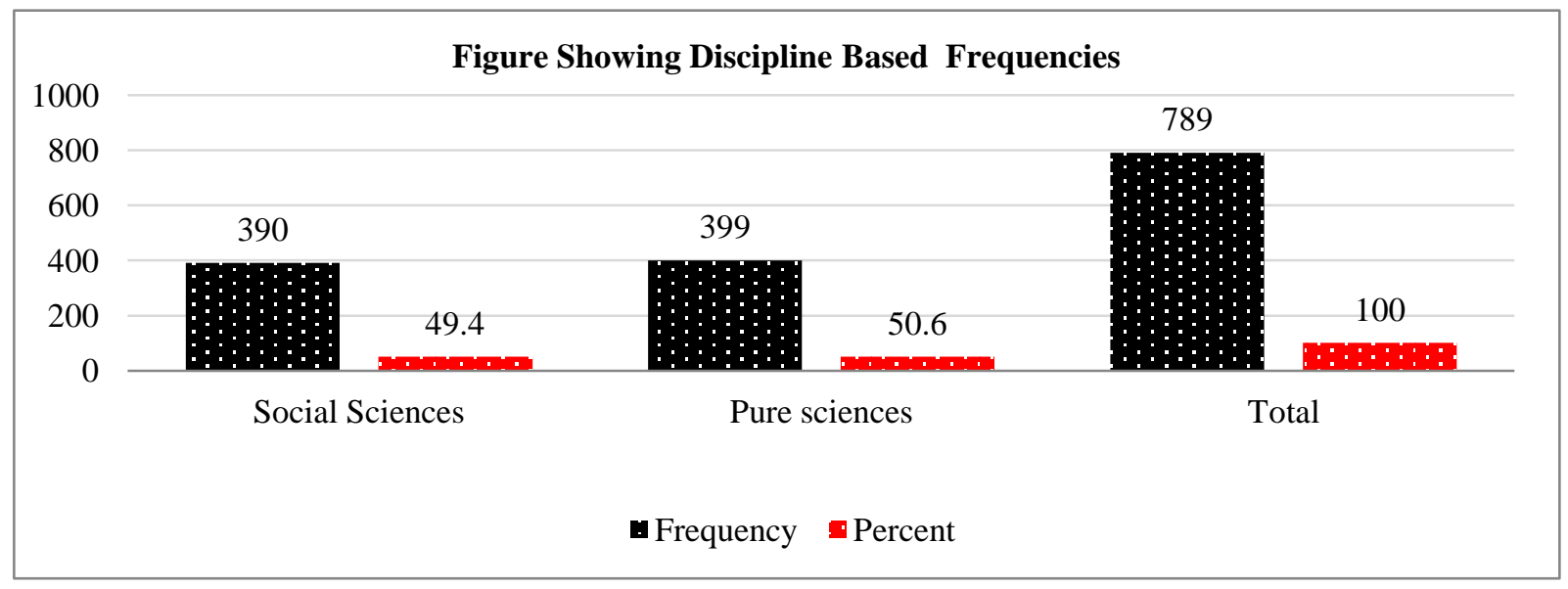

Figure 3: Showing Discipline-Based Frequencies

Source: Authors

Table 5: University-Based Frequencies

\begin{tabular}{llllll}
\hline & Universities & Frequency & Percent & Valid Percent & Cumulative Percent \\
\hline \multirow{3}{*}{ Valid } & Gomal University & 200 & 25.3 & 25.3 & 25.3 \\
\cline { 2 - 6 } & KKK University Karak & 200 & 25.3 & 25.3 & 50.7 \\
\cline { 2 - 6 } & KUST Kohat & 200 & 25.4 & 25.3 & 76.0 \\
\cline { 2 - 6 } & USTB Bannu & 189 & 24.0 & 24.0 & 100.0 \\
\cline { 2 - 6 } & Total & 789 & 100.0 & 100.0 & \\
\hline
\end{tabular}

Source: Directorate of academics in each university

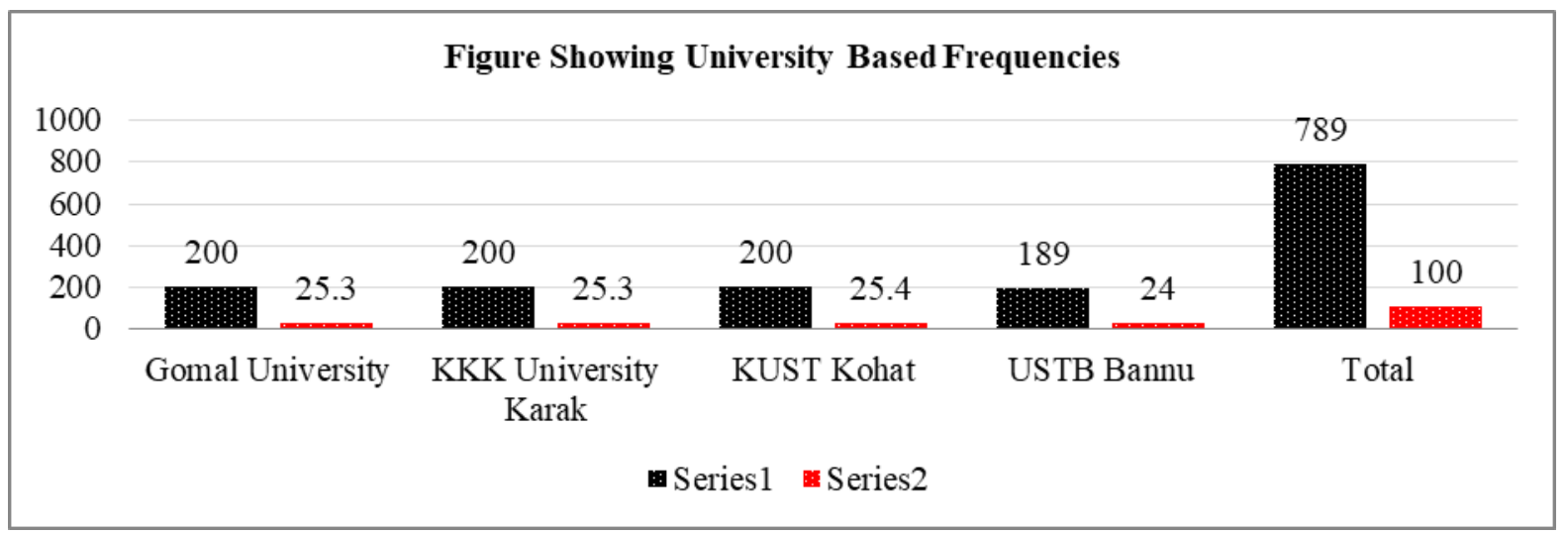

Figure 4: Showing University-Based Frequencies

Source: Directorate of academics in each university

Table 5 along with the figure, reflected university-based frequencies and percentages. The universities were attributed concerning Gomal University, Khushal Khan Khattak University Karak, Kohat University of Science \& Technology Kohat, and the University of Science \& Technology Bannu. In this regard, the respondents who participated in the present study, 
including the 200 (25.3\%), were from the Gomal University, 200 (25.3\%) were from the KKK University Karak, 200 (25.4\%) were from the KUST Kohat, and 189 (24.0\%) were from the USTB Bannu. The analysis revealed that the participants of KUST Kohat University were more than from the other universities in the current research study.

Table 6: Views of Learners Regarding Twitter's Role in English Language Learning

\begin{tabular}{lcccc}
\hline Scale used & \multicolumn{5}{c}{ Frequency } & Percent & Valid Percent & Cumulative Percent \\
\hline Nil & --- & --- & ---- & --- \\
\hline Minimum & --- & --- & --- & --- \\
\hline Medium & 113 & 14.3 & 14.3 & 14.3 \\
\hline High Value & 95 & 12.0 & 12.0 & 26.4 \\
\hline Very High Value & 581 & 73.6 & 73.6 & 100.0 \\
\hline Total & 789 & 100.0 & 100.0 & \\
\hline
\end{tabular}

Source: Directorate of academics in each university

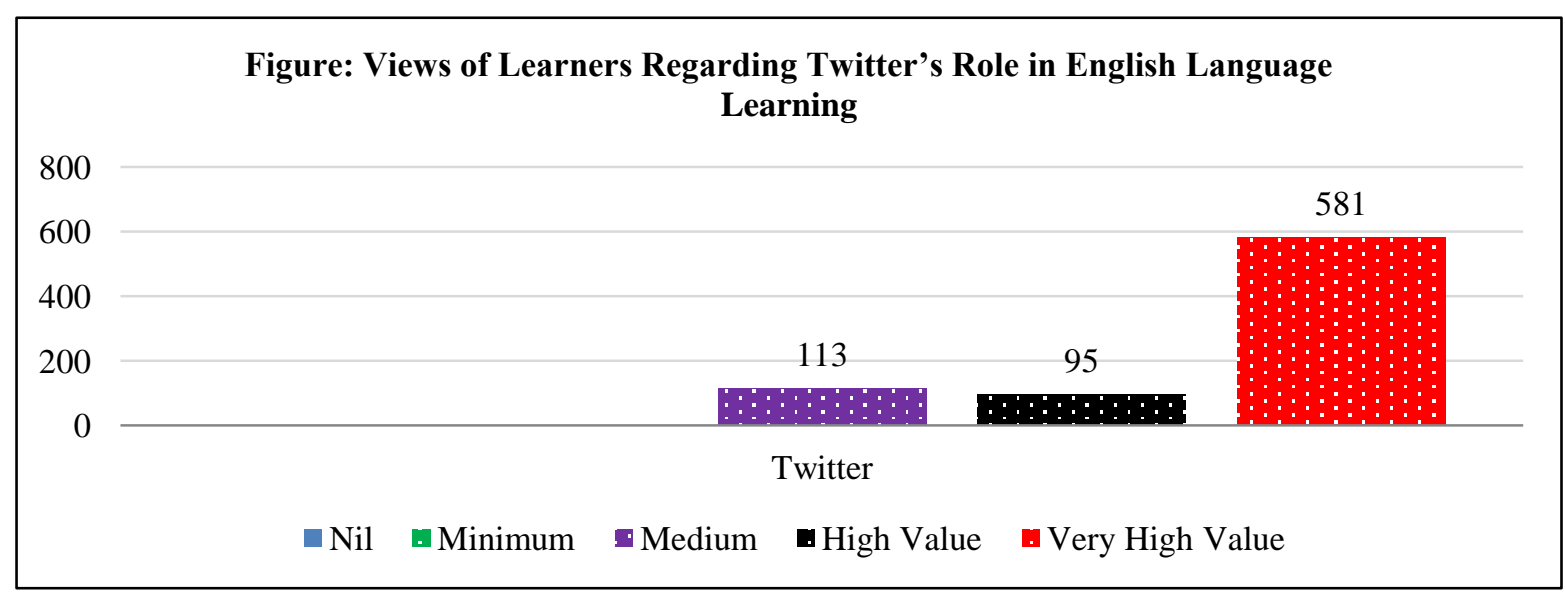

Figure 5: Views of Learners Regarding Twitter's Role in English Language Learning

Source: Directorate of academics in each university

Table 6 along with the figure, indicates that the views of university-level learners regarding Twitter in English language learning proficiency, i.e., Nil, and minimum are zero responses, medium 113, high value 95, and similarly, very high value is 581. In addition, the number of high-value and very high-value respondents is compared to nil, minimum, and medium. Thus it showed that Twitter also plays an important role in English language learning proficiency at the university level in light of the views collected in this present study.

Table 7: Ranking of Social Media Sources across Gender Groups

\begin{tabular}{lllllll}
\hline Statement & Gender & N & Mean & Std. Deviation & F & Sig. \\
\hline \multirow{2}{*}{ Twitter } & Male Students & 400 & 4.4950 & .80722 & \multirow{6}{*}{64.024} & .000 \\
\cline { 2 - 5 } & Female Students & 389 & 4.6941 & .61885 & & \\
\hline
\end{tabular}

Source: Directorate of academics in each university

Table 7 shows the ranking of various social media sources by indicating the views of English language learners regarding the use of Twitter for English language learning proficiency development at the university level. The mean score of male respondents is 4.4950 , the standard deviation is .80722 , and the mean score of female respondents is 4.6941 , the standard deviation is .61885, F-value 64.024, and with sig. .000. Thus, it shows that, like the other social media sources which are mentioned in the said study, Twitter is also helpful in English language learning proficiency development at the university level and plays a pivotal role that may not be neglected.

Table 8: Ranking of Social Media Sources across Discipline

\begin{tabular}{lllllll}
\hline Statement & Discipline & N & Mean & Std. Deviation & F & Sig. \\
\hline \multirow{2}{*}{ Twitter } & Social Sciences & 390 & 4.6462 & .68994 & \multirow{2}{*}{14.434} & .000 \\
\cline { 2 - 5 } & Pure sciences & 389 & 4.5296 & .76474 & & \\
\hline
\end{tabular}

Source: Directorate of academics in each university 
Table 8 reveals the ranking of various social media sources by indicating the views of English language learners regarding the use of Twitter for English language learning proficiency at the university level in which the Mean score of social sciences respondents is 4.6462, Standard Deviation is .68994, and Mean Score of pure sciences respondents is 4.5296, Standard Deviation is .76474, F-value 14.434, and P-value is .000 . Thus, it shows that, like the other social media sources which are mentioned in the said study, Twitter is also helpful in English language learning proficiency development at the university level and plays a pivotal role that may not be neglected.

Table 9: Ranking of Social Media Sources across Gender Groups (ANOVA)

\begin{tabular}{lllllll}
\hline Statement & Relationship & Sum of Squares & df & Mean Square & F & Sig. \\
\hline \multirow{3}{*}{ Twitter } & Between Groups & 7.817 & 1 & 7.817 & & \\
\cline { 2 - 5 } & Within Groups & 408.586 & 787 & .519 & & \\
\cline { 2 - 5 } & Total & 416.403 & 788 & & & .000 \\
\hline
\end{tabular}

Source: Directorate of academics in each university

Table 9 indicates the ranking of various social media sources by revealing the views of English language learners regarding the use of Twitter for English language learning proficiency at the university level in which the Sum of Squares Between groups 7.817 and within groups 408.586, df 1, 787, Mean Squares 7.817, and .519, F-value 15.056, and P-value is 000. Thus, it shows that, like the other social media sources which are mentioned in the said study, Twitter is also helpful in English language learning proficiency at the university level and plays a pivotal role that may not be neglected.

Table 10: Ranking of Social Media Sources across Discipline (ANOVA)

\begin{tabular}{lllllll}
\hline Statements & Relationship & Sum of Squares & df & Mean Square & F & Sig. \\
\hline \multirow{3}{*}{ Twitter } & Between Groups & 4.324 & 2 & 2.162 & & \\
\cline { 2 - 5 } & Within Groups & 412.079 & 786 & .524 & & \\
\cline { 2 - 5 } & Total & 416.403 & 788 & & & \\
\hline
\end{tabular}

Source: Directorate of academics in each university

Table 10 shows the ranking of various social media sources by indicating the views of English language learners regarding the use of Twitter for English language learning proficiency at the university level. The Sum of Squares Between groups 4.324 and within groups 412.079, df 2, 786, mean squares 2.162, and .524, F-value 4.124 and P-value is .017. Thus, it shows that, like the other social media sources which are mentioned in the said study, Twitter is also helpful in English language learning proficiency at the university level and plays a pivotal role that may not be neglected.

\section{DISCUSSION}

The current study results indicate that social media, especially "Twitter" plays an important role in the teaching-learning process. It is a fact that social media sources provide the opportunities of sharing thoughts and views, getting knowledge, presenting comments on various points which are shared by others on social media sources like Facebook. According to Carlson (2005), previous research studies revealed that students learn through social media sources because it is a new learning method. Jenkins (2006) explained that it is interested in learners and learners learning new things and improving their knowledge in a very easy, interesting manner; therefore, the educators should give preference to these new learning methods. O'Keeffe \& Clarke-Pearson (2011) suggest that social media facilitates the English learners to discuss their homework outside the classroom with their class-fellows and teachers. If they feel any difficulty regarding their homework, they may easily get help from other class fellows and even teachers. Sturm et al. (2009) described that it's due to the reason of Web 2.0 technologies that the second language learning or acquisition has been changed from cognitive orientation to social orientation. Block (2003) found that language learning is not limited to the classroom environment in this competitive age, but the learners may learn the second language even outside the classroom. Anonymous (2007) explained that Web 2.0 is a platform is used as a term for the World Wide Web from a combination of websites. It is referred to as the second generation of internet-based services such as social networking, social networking sites, wikis, communication tools, and folksonomies that emphasize online collaboration and sharing among users.

Solomon \& Schrum (2007) described that Web 2.0 is basically a conceived term, and Tim O'Reilly first used it in 2004 . The importance of social media sources in a very beautiful manner that these social media sources enhance the learning environment and play a dominant role in knowledge sharing and increase in knowledge. The other point is that it increases the interaction in the learning process.

Shih \& Yang (2008) described the role of social media in a very clear manner that social media application and use of technology allow the learners to interact with others like exchange of ideas and sharing of information to establish personal communication. The role of social media in communication and sharing of information may not be neglected. Harrison \& Thomas (2009) mentioned the use of social networking is much more used abroad for language learning. Social Network sites are also more and more popular and cause users a sense of flow in some of the users. Egbert (2005) highlighted that second or foreign language teaching is both social and interactive. The speaking skills of a foreign language improve through social interaction and conversation of the target language while writing skills may be improved through a literature study of 
previous studies and this practice is easy when language learners use social media for language learning because through social media sources like Facebook the English language learners may do the practice of all the four basic skills of language like listening, speaking, reading and writing. Harrison \& Thomas (2009) cited that social media sources facilitate the English language learners to a greater extent in social interaction and social awareness about the world. The other important point is that the language learners may examine their level of learning through various social media sources. Blattner \& Fiori (2009) revealed that many previous research studies highlighted that networked computer provides the best atmosphere for social interaction regarding language teaching. Social media sources like Facebook and other social media sources provide manyactivities to English language learners to interact with others systematically and adequately both synchronously and asynchronously, not only with non-native speakers of the English language both with native speakers of the English language.

Vygotsky (1978) mentioned that language learning mostly depends on dialogue practice through social networking sites to do the practice of intercommunication with other members of social networking sites. Online sources like social media applications are a new way of learning in the English language learning process. Ryberg \& Christiansen (2008) claimed that the other important aspect of language learning is that social media facilitates English learners to observe before understanding something new and get the experience of it. This process encourages the learners and facilitates them to get confidence and become active and important community members. The other important point is that this process stimulates the learners towards the learning process. Sykes et al. (2008) revealed that computer-mediated communication tools are helpful in the study of language learning and the practice of text-based chatting and multiple online gaming and mobile devices are also very helpful for them. Learners who use social media sources like Facebook are more talented in reading and writing skills of the English language because they do the practice reading and writing properly and use new words and vocabulary in writing skills.

Guamán (2012) described that the next point is that when the English language learners post various things or writing something about their recognition, then all these personal comments and other things improve their language learning skills and competencies. Campbell (2003) presented three important types of blogs that play a pivotal role in the English language learning process. These three types of blogs are important in language learning classrooms and make the learning process effective. The first one is the tutor blog that is used for the practice of daily reading of verbal exchange. The second one is the learner's blog which is used for students writing skills development. In this type, the learners do the practice of writing their ideas and personal experiences, etc. the third one is a class blog, which is used for the whole class, and students do practice language learning is project-based language learning.

\section{CONCLUSION}

In light of the result of the study, it was concluded that Twitter plays a vital role in the development of English language learning proficiency development not only in social sciences but also in pure science, which has been revealed in light of the result of the said study. Thus has been investigated that the views of learners in both social sciences and natural sciences across gender groups that use Twitter play a positive role in English language learning proficiency development.

\section{RECOMMENDATIONS}

The present study's findings indicated the views of English language learners regarding the positive role of Twitter in English language learning proficiency development at the university level. Therefore, it may be recommended that twitter should be introduced as a learning tool which may be used for English language learning purpose.

The findings of the study also highlighted that Twitter use is quite helpful in English language learning proficiency development because it is free from time and place, but at every place, the learners may use youtube to chat with other friends, class fellows, and even with teachers to get help from them and improve language learning skills.

\section{LIMITATION AND STUDY FORWARD}

The present study was conducted in a descriptive survey type. The researcher has included only public sector universities of southern districts in Khyber Pakhtunkhwa; that is why it may be helpful if the same study is conducted in private sector universities as well. The second point is that if the same study may be conducted in the experimental model, it will further highlight the role of Twitter in English language skills development.

\section{AUTHORS' CONTRIBUTION}

Dr. Irfan Ullah Khan is the main contributor to the development of the main theme related to the unique concept.

Dr. Matiullah and Dr. Khurshed Iqbal performed the drafting and revising of the manuscript.

Mr. Mahraban Alam and Dr. Iftikhar Ahmad performed the statistical procedures and interpretation of the statistical analysis. 


\section{REFERENCES}

1. Abu-Bakar, L. A., Ation, R., \& Esa S. M. (2021). Use of Web 2.0 Tools among English Language Instructors of Higher Learning Institutions in Sabah, Malaysia Ilkogretim. Online Elementary Education Journal, 20(5), 476-48.

2. Adanir, A. G. and Muhametjanova, G. (2021) University students' acceptance of mobile learning: A comparative study in Turkey and Kyrgyzstan. Education and Information Technologies.

3. Aguilar R.F. (2018). Twitter as a formal and informal language learning tool: from potential to evidence innovative language teaching and learning at university: integrating informal learning into formal language education. 99-106. https://doi.org/10.14705/rpnet.2018.22.780

4. Ahmed Al-Hunaiyyan et al. (2021). Human-Computer Interaction Perspective on Mobile Learning: Gender and Social Implications. International Journal of Interactive Mobile Technologies, 1(2), 4-20. https://doi.org/10.399 1/ijim.v15i11.21367

5. Ahmed, M.A. (2015). Effect of Twitter on developing writing skills in English as a foreign language. Arab World English Journal (AWEJ), 2, $134-149$.

6. Anonymous (2007). All things web 2.0 directories. Retrieved from http://www.allthingsweb2.com/ (June 5, 2015).

7. Blattner, G., \& Fiori. M. (2009). Facebook in the language classroom: Promises and possibilities. International Journal of Instructional Technology and Distance Learning, 6(1), 7-28.

8. Block, D. (2003). The social turn in second language acquisition. Washington, DC: Georgetown University Press.

9. Blumler, J. G., \& Katz, E. (1974). The uses of mass communications: Current perspectives on gratifications research. Sage Publications Beverly Hills, CA.

10. Borau, K., Ullrich, C., Feng, J., \& Shen, R. (2009). Microblogging for Language Learning. Using Twitter to train communicative and Cultural Competence. In Spaniol M. et al. (Eds.), Advances in web-based learning. Berlin, Germany: Springer, 78-87. https://doi.org/10.1007/978-3-642-03426-8_10

11. Campbell, A. P. (2003). Weblogs for use with ESL classes. The Internet TESL Journal, 9(2), 224-235.

12. Carlson, S. (2005). The net generation goes to college. The Chronicle of Higher Education (October 7). http://chronicle.com/free/v52/i07/07a03401.htm

13. Dunlap, J.C., \& Lowenthal, P.R. (2009). Tweeting the night away: using Twitter to enhance social presence. Journal of Information Systems Education, 20(2), 1-8.

14. Egbert, J. (2005). Flow as a model for CALL research. In I. J. (Eds.), Mahwah, NJ: Lawrence Erlbaum. CALL Research Perspectives, 129-140).

15. Griffin, E. (2012). A First Look at Communication Theory. New York: McGraw-Hill.

16. Grosseck, G., \& Holotescu, C. (2008). Can we use Twitter for educational activities? The $4^{\text {th }}$ International Scientific conference ELSE: E-learning and Software for Education. http://Adl.unap.ro/else

17. Guamán, L. V. (2012). EFL teenagers' social identity representation in a virtual learning community on facebook. Universidad National de Colombia, Facultad de Ciencias Humanas, Departamento de Lenguas Extranjeras. 14 (2), 182.

18. Harrison, R. \& Thomas, M., (2009). Identity in online communities: Social networking sites and language learning. International Journal of Emerging Technologies and Society, 7(2), 109-124.

19. Jenkins, H. (2006). Confronting the challenges of participatory culture: Media education for the $21^{\text {st }}$ century. Chicago: The John D. and Catherine T. MacArthur Foundation.

20. Lasswell, H. (1948). The structure and function of communications in society. In Bryson, L. (Ed.), the communication of ideas, New York: Harper \& Row, 37-51.

21. List, J., \& Bryant, B. (2009). Integrating interactive online content at an Early College high school: An exploration of Moodle, Twitter, and Ning. Meridian, Raleigh, N.C. http://www.ncsu.edu/meridian/winter2009/list/index.html

22. O'Keeffe, G.S., \& Clarke-Pearson, K. (2011). The impact of social media on children, adolescents, and families. Pediatrics, 28, 127. https://doi.org/10.1542/peds.2011-0054

23. Putriand C.M. \& Wahjuwibowo S.I. (2020) Social Media and Communications Strategies Nyambu Village Tabanan Bali to Increase Tourist eco-tourism, Elementary Education Online, 20(4), 389-395.

24. Raacke, J., \& Bonds-Raacke, J. (2008). My Space and Facebook: Applying the Uses and Gratifications Theory to Exploring Friend-Networking Sites. Cyberpsychology \& Behavior, 11(2), 169-175. https://doi.org/10.1089/ cpb.2007.0056

25. Rough. T. (2021), Mobile learning driving the development of higher education through a new vision of teaching methods thanks to educational technology. Online Elementary Education Journal, 20(5), 976-987.

26. Ruggiero, T. E. (2000). Uses and gratifications theory in the $21^{\text {st }}$ century. Mass Communication \& Society, 3, 3-37. https://doi.org/10.1207/S15327825MCS0301_02

27. Ryberg. T., \& Christiansen. E. (2008). Community and social network sites as technology-enhanced learning environments. Technology, Pedagogy, and Education, 17(3), 207- 219. https://doi.org/10.1080/ 14759390802383801

28. Selwyn, N. (2009). E-learning environment: Blogging as a platform for language learning. European Journal of Social Sciences, 9(4), 584-604.

29. Shahzad, K.S., Panwar, H.A., \& Ansari, S. (2021). Impact of computer-mediated instruction on reading proficiency skills of ESL learners at the secondary level, Online Elementary Education Journal, 20(5), 468-475. 
30. Shih, Y.C., \& Yang, M.T. (2008). A collaborative virtual environment for situated language learning using VEC3D. Educational Technology \& Society, 11(1), 56-68.

31. Solomon, G., \& Schrum, L. (2007). Web 2.0 new tools, new schools. OR: Eugene, International Society for Technology in Education.

32. Srinivas, R. (2010). ICT tools for ELT PPT Presentation-Author Stream. Retrieved from http://www.authorstream .com/Presen tation/rangoo-372780-ict- tools-elt- teaching-English-technology-language-esl education-ppt-power point/

33. Sturm, M., Kennell, T., McBride, R., \& Kelly, M. (2009). The pedagogical implications of Web 2.0. Hershey, P.A: Information Science Reference Handbook of research on Web 2.0 and Second Language Learning, 367-384. https://doi.org/10.4018/978-1-60566-190-2.ch020

34. Sykes, J., Oskoz, A., \& Thorne, S. L. (2008). Web 2.0, synthetic immersive environments, and mobile resources for language education. CALICO Journal, 25(3), 528-546. https://doi.org/10.1558/cj.v25i3.528-546

35. Taskiran, A., Koral, E., \& Aydin, A. (2018). Fostering foreign language learning with Twitter: Reflections from English learners. Turkish Online Journal of Distance Education, 19(1), 100-116. https://doi.org/10.17718/t ojde. 382734

36. Tweeternet (2011). What is Twitter and why does it keep following me around? http://tweeternet.com

37. Vygotsky, L. S. (1978). Mind in society: The development of higher psychological processes. Harvard University Press, Cambridge, MA.

38. Yasir M.S. et al. (2020). Communication in the Digital World: An Evaluation of Orthography of WhatsApp Messaging. Elementary Education Online, 20(4), 1809-1821. 